\title{
The Effects of Ultraviolet and X-Radiation Upon the Centrochromatin of Saccharomyces ${ }^{*}$
}

\author{
G. Fred Townsend, Alvin Sarachek and Carl C. Lindegren \\ Biological Research Laboratory, Southern Illinois University, Carbondale, Illinois. \\ Received October 14, 1953
}

Comprehensive analyses of the effects of low doses of ultraviolet or X-rays on the retardation of mitosis by Carlson' and Carlson and Hollaender- revealed that the nuclei in grasshopper neuroblasts are most susceptible to irradiation from interphase through late prophase, during periods, presumably, of intensive synthesis of desoxyribonucleotides. Maximal susceptibility to X-rays occurs at late prophase while greatest sensitivity to ultraviolet occurs at early prophase. Since both ultraviolet and X-rays block formation of desoxyribonucleotides at dosage levels insufficient to affect protein synthesis, ${ }^{3,1}$ the findings of Carlson and Hollaender suggest (1) that some disturbance of the mechanism of chromatin formation underlies the depression of mitotic activity effected by radiation and (2) that ultraviolet and X-rays act upon different phases of chromatin formation.

The differential effects of ultraviolet and X-irradiation on the centrochromatin of Saccharomyces were studied using a tetraploid culture of known resistance to ultraviolet and X-irradiation. ${ }^{\bar{j}, 6}$ The genetics and cytology of this organism have also been described. A single twenty-four hour culture was held at $4^{\circ} \mathrm{C}$ to provide inocula during the experiments. Samples were prepared for irradiation by introducing approximately $1 \times 10^{7}$ cells into $25 \mathrm{ml}$ of glucose, peptone, yeast-extract broth contained in a $250 \mathrm{ml}$ flask. After 24 hours growth at $30^{\circ} \mathrm{C}$, more than 95 per cent of the cells were in the non-budding interphase state, and haematoxylin staining revealed the characteristic spherical centrochromatin. The cells were harvested, washed twice with $\mathrm{M} / 15 \mathrm{KH}_{2} \mathrm{PO}_{4}$ and diluted to a concentration of about $5 \times 10^{5}$ cells per $\mathrm{ml}$. Thirty $\mathrm{ml}$ of the suspension were transferred to sterile petri dishes for irradiation. During irradiation the suspensions were agitated with a magnetic stirrer. X-radiation was delivered at the rate of $1000 \mathrm{r} / \mathrm{min}$. from a tungsten target tube operating at $20 \mathrm{ml} 180 \mathrm{KVP}$. The ultraviolet dosage was delivered at the rate of $5.9 \mathrm{ergs} / \mathrm{mm}^{2} / \mathrm{sec}$. (measured at the surfacc of the dish) by a Hanovia quartz envelope lamp emitting 95 per cent its ultraviolet energy at wave length $2537 \mathrm{~A}$. Five $\mathrm{ml}$ samples were removed from the dishes exposed to $\mathrm{X}$-rays and two $\mathrm{ml}$ of triple strength glucose, peptone, yeast-extract agar were added and the samples incubated at $30^{\circ} \mathrm{C}$. Ultraviolet irradiated samples were treated similarly.

* This work was supported by research grants from the Atomic Energy Commission, the Office of Naval Research (NR 164-140) and Anheuser-Busch, Ine. 
The centrochromatin ${ }^{8}$ in the yeast cell exists in interphase as a spherical body in joint contact with the nuclear vacuole and the spindle (Fig. 1A). In interphase cells which have been irradiated with lethal doses of X-rays (i.e. doses which preclude formation of macroscopic colonies upon plating) crescent formation occurs, apparently normally, while in similar cells exposed to sublethal doses of ultraviolet irradiation, crescent formation is delayed for from two to three hours.

The disruption of mitochondria reported by Sarachek and Townsend ${ }^{9}$ is observed in cells with conspicuous mitochondria grown under special conditions. The treated cells described above were prepared under conditions in which the mitochondria are quite inconspicuous (without heavy fat deposits) and no observable disruption occurred.

The following tabulation presents data on the effects of different doses of radiation upon the delay in formation of the crescent centrochromatin in Saccharomyces in comparision with the degrees of cellular inactivation and retardation of budding produced by comparable amounts of irradiation.

\begin{tabular}{|c|c|c|c|c|}
\hline & Dosage & $\begin{array}{c}\text { Percen- } \\
\text { tage } \\
\text { Inacti- } \\
\text { vation }\end{array}$ & $\begin{array}{l}\text { Pereentaga } \\
\text { Retardation } \\
\text { of Budding }\end{array}$ & $\begin{array}{l}\text { Delay in } \\
\text { Crescent } \\
\text { Forma- } \\
\text { tion }\end{array}$ \\
\hline U.V. & $\begin{array}{l}\mathrm{gs} / \mathrm{mm}^{2} \\
\quad 59 \\
\left(\begin{array}{r}885 \\
(1475\end{array}\right.\end{array}$ & $\begin{array}{r}0 \\
55 \\
99\end{array}$ & $\begin{array}{r}0 \\
85 \\
100\end{array}$ & $\begin{array}{c}2-3 \mathrm{hrs} \\
18-20 \mathrm{hrs}\end{array}$ \\
\hline X-Ray & $\begin{array}{l}\mathrm{r} / \min \\
\left(\begin{array}{r}500 \\
(1800 \\
(60000\end{array}\right.\end{array}$ & $\begin{array}{c}0 \\
55 \\
99.8\end{array}$ & $\begin{array}{r}0 \\
35 \\
60\end{array}$ & $\begin{array}{l}\text { None } \\
\text { None } \\
\text { None }\end{array}$ \\
\hline
\end{tabular}

Unirradiated control cells commence budding after 90 minutes and complete the development of at least one mature bud at the

Fig. 1. The normal formation of the centrochromatinic crescent during transition from interphase through prophase. Cells are stained with Heiden. hains haematoxylin. A. Interphase: a Spindle. b Sphere of centrochromatin. c Vacuole. B. Early prophase. Crescent formation beginning. C. Budding cell. Crescent complete.
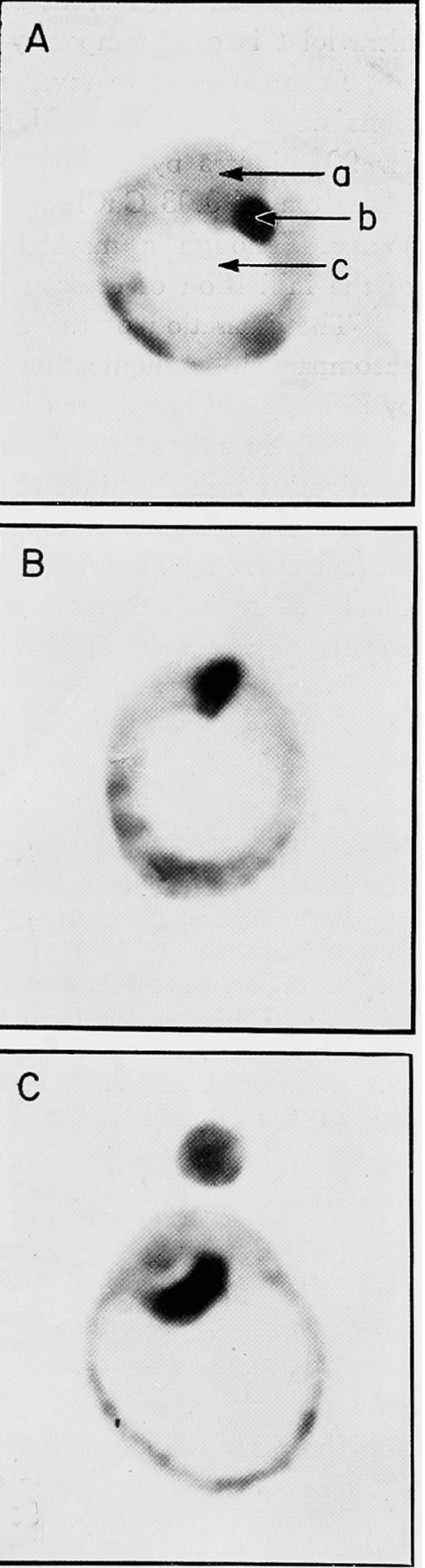
end of three hours; crescent formation is completed ten to fifteen minutes before the onset of budding. The haematoxylin stain revealed that cells exposed to the maximal X-ray dosage are capable of producing crescents as readily as control cells, while those exposed even to the minimal ultraviolet dose fail to effect crescent formation within normal time. The effect of the ultraviolet is only temporary; eventually all cells form crescents.

In an attempt to reverse the action of ultraviolet, irradiated cell suspensions were placed in $25 \mathrm{ml}$ flasks held at $30^{\circ} \mathrm{C}$ and illuminated from below for 90 minutes by a 500 Watt Fresenel Spot Lamp at a distance of $15 \mathrm{~cm}$. Three $\mathrm{cm}$ of $0.03 \mathrm{CuCl}_{\text {, }}$, were interposed between the flasks and the light source. Though a marked increase in cell survivals resulted, no reduction of the inhibition of crescent formation was detected.

The formation of the crescent of centrochromatin preceding budding is accompanied by duplication of the cellular DNA. ${ }^{10}$ It has been established, by Kelner, that low doses of ultraviolet radiation immediately suspend synthesis of DNA in micro-organisms, and that this inhibition is readily removed by reactivating light. ${ }^{3}$ Since the ultraviolet induced inhibition in Saccharomyces is not photoreversible and the inactivating doses of X-ray (which should prevent DNA synthesis) fail to affect the progress of crescent formation, the effects of radiations upon the prophase arrangement of centrochromatin in Saccharomyces may not be related directly to their effects upon DNA synthesis.

\section{References}

1. J. G. Carlson 1942. J. Morph. 71, 449.

2. - and A. Hollaender 1944. J. Cell and Comp. Physical. 23, 157.

3. A. Kelner 1953. J. Bact. 65, 252

4. J. S. Mitchell 1942. Brit. J. Exp. Path. 23, 285.

5. A. Sarachek and W. H. Lucke Arch. Biochem. and Biophys. (in press).

6. W. H. Lucke and A. Sarachek 1953. Nature, 171, 1014.

7. C. C. Lindegren and G. Lindegren 1951. J. Gen. Microb. 5, 885.

8. G. F. Townsend and C. C. Lindegren Cytologia (in press).

9. A. Sarachek and G. F. Townsend 1953. Science 117, 31

10, M. Ogur, S. Minckler and D. O. MeClary J. Bact. (in press). 